\title{
Seroprevalence studies of bovine brucellosis using indirect- enzyme-linked immunosorbent assay (i-ELISA) at organized and unorganized farms in three different states of India
}

\author{
Ramesh V. Jagapur, Rajesh Rathore, K. Karthik and Ramesh Somavanshi \\ Indian Veterinary Research Institute, \\ Izatnagar - 243122, Dist. Bareilly, Uttar Pradesh, India \\ Corresponding author: Ramesh V. Jagapur, email:jagapurrv@gmail.com \\ Received: 04-03-2013, Revised: 03-04-2013, Accepted: 04-04-2013, Published online: 05-06-2013
}

How to cite this article: Jagapur RV, Rathore R, Karthik K and Somavanshi R (2013) Seroprevalence studies of bovine brucellosis using indirect-enzyme-linked immunosorbent assay (i-ELISA) at organized and unorganized farms in three different states of India, Vet World 6(8): 550-553, doi: 10.5455/vetworld.2013.550-553

\begin{abstract}
Aim: The present study was undertaken to know the seroprevalence of brucellosis in cattle and buffaloes. The work was carried out during the period 2011 through 2013 at Centre for Animal Diseases, Research and Diagnostics, IVRI, Izatnagar, Uttar Pradesh, India.

Materials and Methods: A total of 1005 sera samples were collected and tested for bovine brucellosis using ELISA Kit; IDEXX, CHEKIT, Brucellose serum, Brucella abortus Antibody Test Kit

Results: A total of 1005 serum samples were collected from Karnataka, Uttar Pradesh and Uttarakhand during the period of 2011 to 2013 and were screened for bovine brucellosis using i-ELISA (indirect enzyme linked immunosorbent assay). The prevalence of bovine brucellosis was compared between organized and unorganized farms in order to find the epidemiology of the disease among the animal population. Sera from 5 organized farms in Karnataka were collected for seroprevalence studies. Out of 417 animals, 191 (45.80\%) animals were found positive by i-ELISA. A total of 361 serum samples were collected from 5 unorganized farms or villages, of which $82(22.71 \%)$ were positive. From Uttar Pradesh, bovine serum samples were collected from 3 organized farms. Out of 192 animals, 43 (22.39\%) animals were found positive for brucellosis. Similarly, sera collected from a single organized farm from Uttarakhand, showed $3(8.57 \%)$ positivity among 35 animals. On the whole, 319 $(31.74 \%)$ animals were found positive for brucellosis among the 3 states taken for study, which includes $138(27.21 \%)$ cattle and $181(36.34 \%)$ buffaloes.
\end{abstract}

Conclusion: It has been found that Brucella infections are widely prevalent in organized and unorganized dairy farms in investigated states of India.

Keywords: brucellosis, buffaloes, cattle, i-ELISA, seroprevalance

\section{Introduction}

Bovine brucellosis is a major zoonotic disease caused by bacteria which affects both cattle and buffaloes equally. More prevalent in adults while young ones do not show infection till maturity. The bacteria commonly associated with the bovine brucellosis are mainly Brucella abortus, less frequently Brucella melitensis and rarely by $B$. suis [1].

The prevalence of bovine brucellosis in dairy farms has long been reported and studies have confirmed widespread prevalence in different states of India [2, 3].

The control of bovine brucellosis is possible only by accurate diagnosis of the disease at the appropriate time. Diagnostic methods include direct tests, involving isolation of bacteria or DNA detection by polymerase chain reaction (PCR) or loop mediated isothermal amplification (LAMP) methods. Indirect test includes serological tests, which are applied in vitro using milk or plasma or serum and allergic test done in vivo in suspected animals. The gold standard for the diagnosis of brucellosis is isolation, which is the

This article is an open access article licensed under the terms of the Creative Commons Attribution License (http://creativecommons. org/licenses/by/2.0) which permits unrestricted use, distribution and reproduction in any medium, provided the work is properly cited. confirmative test [4]. However, it is time consuming, requires biosafety level-3 facilities and skilled persons to handle samples. The alternative methods involving serological tests are easy, safe, and less time and resource intensive.

The aim of the present study was to study the prevalence of brucellosis in cattle and buffaloes of Karnataka, Uttar Pradesh and Uttarakhand in order to take an effective control measures against contagious infection which causes heavy economic losses.

\section{Materials and Methods}

Ethical consideration: The study was approved by the Institute Animal Ethics Committee. Adequate measures were taken to minimize pain or discomfort to animals in accordance with the Institute Animal Ethics Committee, while collection of samples. The researchers obtained oral consent from dairy farmers during the survey visits.

Study area: The samples were collected from states of Karnataka, Uttar Pradesh and Uttarakhand during the period 2011 through 2013. The laboratory analysis was conducted at Centre for Animal Diseases, Research and Diagnostics (CADRAD), IVRI, Izatnagar(UP).

ELISA kit: The commercial ELISA kit was procured 
Table-1. Prevalence of brucellosis in cattle and buffaloes of three different states of I ndia, assayed using i-ELISA

\begin{tabular}{llccc}
\hline State & Type of Farm & Cattle & Buffalo & Total \\
\hline Karnataka & Organized & $37 / 79(46.83 \%)$ & $154 / 338(45.56 \%)$ & $191 / 417(45.80 \%)$ \\
& Unorganized & $55 / 201(27.36 \%)$ & $27 / 160(16.87 \%)$ & $82 / 361(22.71 \%)$ \\
Uttar Pradesh & Organized & $43 / 192(22.39 \%)$ & - & $43 / 192(22.39 \%)$ \\
Uttarakhand & Organized & $3 / 35(8.57 \%)$ & - & $3 / 35(8.57 \%)$ \\
Total & & $138 / 507(27.21 \%)$ & $181 / 498(36.34 \%)$ & $319 / 1005(31.74 \%)$ \\
\hline
\end{tabular}

from IDEXX-CHEKIT, Brucellose serum (Netherland) to screen bovine brucellosis.

Preparation of sera samples and i-ELISA: The i-ELISA test was validated using positive and negative control sera. After collection of blood from cattle and buffaloes the serum was separated, inactivated at $56^{\circ} \mathrm{C}$ for $30 \mathrm{~min}$ and stored at $-20^{\circ} \mathrm{C}$ till the test was performed. The serum samples were subjected to i-ELISA using manufacturer's protocol.

\section{Results and Discussion}

A total of 1005 serum samples were analysed from 3 states which includes 778, 192 and 35 respectively from Karnataka, Uttar Pradesh and Uttarakhand (Table-1). The low specificity of RBPT and Standard Tube Agglutination Test (STAT) [5-8] made us to use highly specific test like i-ELISA for screening brucellosis.

In Karnataka a total of 5 organized farms with the history of bovine brucellosis were selected for seroprevalence study. Among 417 animals (79 were cattle and 338 were buffaloes), 191 (45.80\%) were found positive. Among the tested animals, 46.83\% $(n=37)$ cattle and $45.56 \%(n=154)$ buffaloes showed reactivity for brucellosis (Table-1). Previously, higher bovine prevalence of $29.0 \%$ was reported, with $38.29 \%$ in cattle and $26.63 \%$ in buffaloes in Central Gujarat using ELISA [9], 33.33\% in cattle by employing ELISA [10], $38.95 \%$ in buffaloes of Northern Gujarat [11] and $26.50 \%$ by ELISA in cattle and buffaloes from 3 different states [12]. However, some studies have reported a lower seroprevalence $[13,14]$ in Uttaranchal (4.6\%) and Gorakhpur district of Uttar Pradesh (3.11\% cows and $4.18 \%$ buffaloes) by i-ELISA. Also, a low seroprevalence of $1.9 \%$ in cattle and $1.8 \%$ in buffalo were reported on serological survey of 19 states in India [15]. The high seroprevalence of brucellosis was recorded in our study, because the samples were collected at the phase of out break, when the heard showing signs of abortion, retained placenta and infertility in the farms.

A total of 361 sera samples (201 cattle and 160 buffaloes) were collected from 5 unorganized farms or villages of Karnataka. Of this, total of 82 (22.71\%) were positive for brucellosis reactivity. This included $27.36 \%(n=55)$ cattle and 16.87\% (27) buffaloes (Table-1).

The over all prevalence of $22.71 \%$ observed in unorganized farms of Karnataka (Table-1) was comparable with previous reports of average $25 \%$ seroprevalence overall and $24.30 \%$ in cows and $26.03 \%$ in buffaloes as detected by i-ELISA [5]. However, a prevalence $21.74 \%$ was reported in endemic areas [16]. Similar reports were shown with $19.12 \%$ $(n=48)$ positive out of 251 sera tested for brucellosis with i-ELISA in Anand, Vadodara and Kaira districts [3]. Gender wise, $18.70 \%(n=43)$ were found positive out of 230 females and $23.81 \%(n=5)$ were found positive among 21 males by i-ELISA [3]. Also, prevalence of $23.79 \%$ was found in 374 yaks using AB -ELISA in seroprevalence studies of north-eastern hilly yak tracts of Arunachal Pradesh [17].

The prevalence of brucellosis in unorganized farms was noticed less compared to organized farms; it may due to break in chain of disease spread among discrete populations.

A total of 192 bovine serum samples were collected from 3 organized farms of Uttar Pradesh, 22.39\% $(n=43)$ animals were found positive for brucellosis using i-ELISA. However earlier study using i-ELISA had observeda lower prevalence of $3.11 \%$ in cows and $4.18 \%$ in buffaloes from Gorakhpur district of Uttar Pradesh[10]. A single organized dairy farm was taken for seroprevalence studies in Uttarakhand. Out of 35 animals, $n=3(8.57 \%)$ animals showed positive reaction by $i$-ELISA.

Overall, in our study, $319(31.74 \%)$ animals were found positive for brucellosis out of total 1005 in all the 3 states taken together, that includes 138 (27.21\%) cattle and $181(36.34 \%)$ buffaloes (Table- 1$)$. The high prevalence rate of brucellosis in buffaloes compared to cattle could be due to the use of infected buffalo bulls in natural service and rare use of artificial insemination in the farms. Similar findings were observed by other researchers $[10,11]$.

Comparison of the prevalence between organized and unorganized farms in Karnataka showed $45.80 \%$ $(n=191$ out of 417 samples) and $22.71 \%(n=82$ out of 361 samples) (Table-1). However, previous reports indicated $22.18 \%$ animals sero-positive by i-ELISA in organized dairy farms with history of abortion in India [18]. Also, in contrary to our work, a study in Punjab revealed that organized farms had lower prevalence in well managed farms $(5.2 \%)$ when compared to unorganized poorly managed farms (14.81\%) [19].

The lower prevalence of brucellosis can be achieved or it can be eliminated from an organized farm with regular screening and removal of reactive animals with highly specific screening test like iELISA. Also, false positive reactions shown by Rose Bengal Precipitation Test (RBPT) can be avoided in iELISA [20]. The i-ELISA was found to be the more sensitive among the tests used for screening brucellosis $[3,8]$ and it detected $96(14.46 \%)$ sera samples positive for brucellosis [21]. It is considered as gold standard 
test by many workers to compare the results of other tests in case of brucellosis [22]. ELISA has been reported to be more sensitive compared to other conventional tests [23]. It suggests that i-ELISA could replace not only the currently used confirmatory CFT (Complement Fixation Test) [24], but also other two routine screening tests, namely the RBPT and STAT [25].

The i-ELISA, under laboratory conditions is sensitive as radio immunoassay but can also be adopted as simple field screening procedures [26]. Similarly higher efficacy of i-ELISA was found in cattle [27] and buffaloes [5]. It may be concluded that i-ELISA is a better serological test compared to RBPT and STAT and it could be advocated for screening of brucellosis. The validation and extensive use of primary binding assays like i-ELISA has made diagnosis of bovine brucellosis more manageable [28].

\section{Conclusion}

Present finding, reveals high prevalence of bovine brucellosis in organized farms as compared to unorganized farms, which is due to spread of infection from one animal to other by contact between the females or during natural service with infected bull. The highly sensitive and specific diagnostic test i.e. ELISA helps in screening of bovine brucellosis at the low titre compared to RBPT, STAT and other diagnostic tests.

\section{Authors' contribution}

This work was carried out by RJ under the guidance of RR with technical and administrative support of RS. KK collected material for manuscript. All authors read and approved the final manuscript.

\section{Acknowledgements}

Authors are grateful to Director and Joint Director (Research), Indian Veterinary Research Institute Izatnagar, Bareilly and Commissioner, Animal Husbandry \& Veterinary Services, Bangalore to take up this study and funding for research work.

\section{Competing interests}

The authors declare that they have no competing interests.

\section{References}

1. Corbel, M. J. and Brinley-Morgan, W. J. (1984) Genus Brucella, Meyer and Shaw, 1920, 173AL. In: Krieg, N.R. and Holt, J.B. (eds.) Bergey's Manual of Systemic Bacteriology, Vol. 1. Williams \& Wilkins, Baltimore.

2. Agrawal, R., Kumar, M. and Singh, J. L. (2007) Seroprevalence of brucellosis in Uttaranchal. Indian Vet. J., 84: 204205.

3. Brahmabhatt, M. N., Varasada, R. N., Bhong, C. D. and Nayak, J. B. (2009) Seroprevalence of Brucella spp. in buffaloes in the central Gujarat region of India. Buffalo Bull., 28(2): 73-75

4. Godfroid, J., Nielsen, K. and Saegerman, C. (2010) Diagnosis of Brucellosis in Livestock and Wildlife. Croatian Med. J., 51:296-305.

5. Godsara, S. N., Roy, A. and Bhanderi, B. B. (2010) Comparison of Rose Bengal Plate Agglutination, Standard tube agglutination and Indirect ELISA tests for detection of
Brucella antibodies in cows and buffaloes. Vet. World, 3(2): 61-64.

6. Kanani, A.N. (2007) Serological, cultural and molecular detection of Brucella infection in breeding bulls. Ph.D. thesis (Veterinary Microbiology) submitted to Anand Agricultural University, Anand.

7. Otlu, S., Sahin, M., Unver, A. and Celebi, O. (2007) Detection of Brucella melitensis and Chlamydiophila abortus antibodies in aborting sheep in the Kars provinces of Turkey. Bull. Vet. Inst., 51: 493-495.

8. Prithiviraj (2010) Comparison of different serological test for diagnosis of bovine brucellosis. M.V.Sc thesis (Epidemiology) submitted to Deemed University, Indian Veterinary Research Institute, Izatnagar, UP.

9. Patel, T. J. (2007) Serological, cultural and molecular detection of Brucella infection in bovines quantification in milk by real time PCR. M.V.Sc. thesis (Veterinary Microbiology) submitted to Anand Agricultural University, Anand.

10. Chakraborty, M., Patziri, G. P. and Sharma, D. K. (2000) Use of Rose Bengal plate test, serum agglutination test, I-ELISA for detecting brucellosis in bovines. Indian J. Comp. Microbiol. Immunol. Infect. Dis.,21:24-25.

11. Chauhan, H. C., Chandel, B. S. and Shah, N. M. (2000) Seroprevalence of brucellosis in buffaloes in Gujarat. Indian Vet.J., 77: 1105-1106.

12. Chand, P. and Sharma, A. K. (2004) Situation of brucellosis in bovines at organized cattle farms belonging to three different states. J.of Immunol. And Immunopath., 6: 11-15.

13. Bhattacharya, D. K., Ahmed, K. and Rahman, H. (2005) Studies on seroprevalence of bovine brucellosis by different tests. J. Vet. Pub. Health., 3: 131-133.

14. Mishra, V. K., Arora, S. and Bist, B. (2005) Seroprevalence of brucellosis among cows and buffaloes of Gorakhpur district of Uttar Pradesh. J. Vet. Pub. Health., 3: 67-70.

15. Isloor, S., Renukaradhya, G. J. and Rajasekhar, M. (1998) A serological survey of bovine brucellosis in India. Rev. Sci. Tech. Off. Int. Epizoot., 17: 781-785.

16. Chandramohan C. P., Ramadass P. and Raghavan N. (1992) Studies on bovine brucellosis in an endemic area. Indian Vet. J., 69: 581-583.

17. Bandyopadhyay, S., Sasmal, D., Dutta, T. K., Ghosh, M. K., Sarkar, M., Sasmal, N. K. and Bhattacharya, M. (2009) Seroprevalence of brucellosis in yaks (Poephagus grunniens) in India and evaluation of protective immunity to S19 vaccine. Trop. Anim. Health. Prod., 41(4): 587-92.

18. Trangadia, B., Rana, S. K., Mukherjee, F. and Srinivasan, V.A. (2010) Prevalence of brucellosis and infectious bovine rhinotracheitis in organized dairy farms in India. Trop. Anim. Health. Prod., 42: 203-207.

19. Singh, G., Sharma, D. R. and Dhand, N. K. (2004) Seroprevalence of bovine brucellosis in Punjab. Indian Vet. J., 81: 620-623.

20. Akhtar, R., Chaudhry, Z., Shakoori, A.R., Ahmad, M. and Aslam, A. (2010) Comparative efficacy of conventional diagnostic methods and evaluation of polymerse chain reaction for the diagnosis of bovine brucellosis. Vet. World, 3(2): 53-56

21. Sunder, A. (2012) Prevalence study of bovine brucellosis based on conventional and molecular technique. M.V.Sc thesis (Epidemiology) submitted to Deemed University, Indian Veterinary Research Institute, Izatnagar, UP.

22. Nielsen, K., Smith, P., Gall, Perez, D., Cosma, C., Mueller, P., Trottier, J. and Bosse, J. (1996) Development and validation of an indirect enzyme linked immunosorbent assay for detection for detection of antibody to Brucella abortus in milk. Vet. Microbiol., 52: 165-173.

23. Al Dahouk, S., Tomaso, H., Nockler, K., Neubauer, H. and Frangoulidis, D. (2003) Laboratory-based diagnosis of brucellosis - a review of the literature. Part I:Techniques for direct detection and identification of Brucella spp. Clin. Lab., 49: 487-505.

24. Nielsen, K. and Yu, W.L. (2010) Serological diagnosis of 
brucellosis. Conributions, Sci. Biol. Med. Sci. MASA, XXXI, 1: 65-89.

25. Paweska, J. T., Potts, A. D., Harris, H. J., Smith, S. J., Viljoen, G. J., Dungu, B., Brett, O. L., Bubb, M. and Prozesky, L. (2002) Validation of an indirect enzyme-linked immunosorbent assay for the detection of antibody against Brucella abortus in cattle sera using an automated ELISA workstation. Onderstepoort J. Vet. Res.,69: 61-77.

26. Nielsen, K., Gall, D., Smith, P., Y. W., Nicoletti, P., Elzer, P., Silva, P., Moreno, F., Ruiz, A., Kenny, K., Perez, B. and
Hallbert, G. (2005) Evaluation of serological tests for detection of caprine antibody to Brucella melitensis. Small Rum. Res., 56: 253-258.

27. Ekgatat, M., Thammasart, S., Kanitpun, R., Wongkasemjit, S., Nokdhes, C. and Trenuntawan, U. (2008) Indirect EnzymeLinked Immunosorbent Assay Test Kit Development for Specific Antibody Detection Against Brucella abortus in Cattle. Kasetsart J. (Nat. Sci.)., 42:95-100.

28. OIE (2009) Bovine Brucellosis (Chapter 2.4.3). OIE Terrestrial Manual 2009. p: 1-35.

$* * * * * * * *$ 